\title{
NATURAL LANGUAGE PROCESSING (NLP) UNTUK MENGETAHUI HUKUM BACAAN AL-QUR'AN
}

\author{
Heriyanto'), Sri Hartati²) \\ 1) Prodi Teknik Informatika UPN "Veteran" Yogyakarta \\ Jl. Babarsari 2 Tambakbayan 55281 Telp(0274) 485323 \\ Email : $\mathrm{mr}$ heriyanto skom@yahoo.com \\ 2) Prodi Ilmu Komputer UGM Yogyakarta \\ Gedung S2/S3 FMIPA UGM Lantai IV, \\ Sekip Utara Yogyakarta 55281, Kotak Pos BLS 21 Telp/Fax (0274) 555133 \\ Email : shartati@ugm.ac.id
}

\begin{abstract}
Natural Language Processing (NLP) to know Al-Quran reading law can analyse text data input in the form of sentence with everyday human being language of process early by recognizing syntak order and existing production order through scanning, identifying token, result of from token will be conducted by parsing and processed later; then to be conducted by adaptation with existing production order. Result of adaptation will in accepting or is not accepted by if do not fulfill existing production order will emerge message of mistake. The result if as according to order produce hence will present as according to wanted sentence to present Al-Quran reading law. Knowing real correct Al-Quran reading law as according to tartil, its science of its law nya of kifayah fardhu, therefore in studying and knowing Al-Quran reading law by using Natural Language Processing (NLP) can fulfill science procedures learn to read AlQuran matching with tajwid science. NLP which can recognize wanted reading law by consumer for the letter of Al-Fatihah, Al-Baqarah Juz 1. made Application Software can give appearance result of Al-Quran reading laws, NLP which can analyse about wanted reading law with input pass text. Read text pursuant to used production order so that can know reading law which is pursuant to included text
\end{abstract}

\section{Keywords: scanning, token, parsing, Al-Quran, tajwid, juz, natural Language Processing}

Natural Language Processing (NLP) untuk mengetahui hukum bacaan Al-Quran dapat menganalisis masukan data teks berupa kalimat dengan bahasa manusia sehari-hari proses awal dengan mengenali aturan syntak dan aturan produksi yang ada dengan melalui scanning, mengidentifikasi token, hasil dari token akan dilakukan parsing dan diproses kemudian untuk dilakukan pencocokan dengan aturan produksi yang ada. Hasil pencocokan akan di terima atau tidak diterima apabila tidak memenuhi aturan produksi yang ada akan muncul pesan kesalahan. Hasil tersebut apabila sesuai dengan aturan produksi maka akan menampilkan sesuai dengan kalimat yang diinginkan untuk menampilkan hukum bacaan Al-Quran. Mengetahui hukum bacaan Al-Quran yang benar sesuai dengan tartil, ilmu tajwidnya hukumnya fardhu kifayah, oleh karena itu dalam mempelajari dan mengetahui hukum bacaan Al-Quran dengan menggunakan Natural Language Processing (NLP) dapat memenuhi tata cara ilmu belajar membaca Al-Quran yang sesuai dengan ilmu tajwid. NLP yang dapat mengenali hukum bacaan yang diinginkan oleh pengguna untuk surat Al-Fatihah, Al-Baqarah juz 1. Aplikasi perangkat lunak yang dibuat dapat memberikan tampilan hasil hukum-hukum bacaan Al-quran, NLP yang dapat menganalisa tentang hukum bacaan yang diinginkan dengan input melalui teks. Teks yang dibaca berdasarkan aturan produksi yang digunakan sehingga dapat mengetahui hukum bacaan yang berdasarkan teks yang dimasukkan.

Kata kunci : scanning, token, parsing, Alquran, tajwid, juz,Natural language Procesing

\section{PENDAhUluan}

Natural Language Processing (NLP) untuk mengetahui hukum bacaan Alquran dapat menganalisis masukan data teks berupa kalimat dengan bahasa manusia sehari-hari proses awal dengan mengenali aturan syntak dan aturan produksi yang ada dengan melalui scanning, 
mengidentifikasi token, hasil dari token akan dilakukan parsing dan diproses kemudian untuk dilakukan pencocokan dengan aturan produksi yang ada. Hasil pencocokan akan di terima atau tidak diterima apabila tidak memenuhi aturan produksi yang ada akan muncul pesan kesalahan. Pesan kesalahan tersebut diberitahukan kepada pengguna untuk dilakukan perbaikan. Hasil tersebut apabila sesuai dengan aturan produksi maka akan menampilkan sesuai dengan kalimat yang diinginkan untuk menampilkan hukum bacaan Alquran.

Belajar ilmu Alquran hukumnya Fardhu kifayah, sedang membaca Al-Qur'an dengan baik (sesuai dengan ilmu tajwid) hukumnya Fardhu 'Ain (Zarkasyi, Imam, KH, 1995). Kegiatan untuk mengetaahui hukum bacaan dengan menginput teks misalkan "tampilkan surat albaqarah ayat 3" maka muncul hukum-hukum bacaan Al-Quran. Bagaimana kalau yang menunjukkan hukum bacaan ditemukan dengan contoh-contoh hukum bacaan di dalam Al-quran dengan menginputkan teks yang diinginkan.

\section{RUMUSAN MASALAH}

Adapun rumusan masalah

1. Bagaimana membuat aplikasi NLP yang dapat mengelola hukum bacaan Alquran yang diinginkan di dalam teks agar dapat memberikan tampilan hasil sesuai dengan keinginan pengguna dengan memasukkan berupa kalimat bahasa alami manusia.

2. Bagaimana untuk membuat aturan produksi, syntak, token, parsing dalam NLP yang dapat mengenali hukum bacaan yang diinginkan oleh pengguna.

\section{Batasan masalah}

1. Surat Al-Fatihah, Surat Al-Baqarah Juz 1

2. Nama hukum bacaan yaitu idhar, qolqolah, iqlab, idhghombigunnah, idghombilagunnah, ikhfak.

\section{TUJUAN DAN MANFAAT PENELITIAN}

Adapun tujuan penelitian sebagai berikut :

1. Menghasilkan Aplikasi perangkat lunak NLP yang dapat memberikan tampilan hasil hukum-hukum bacaan Al-quran sesuai dengan input teks berupa bahasa alami manusia.

2. Menghasilkan analisa berupa aturan produksi, syntak, token, parshing yang tepat untuk bahasa alami dalam mencari hukum bacaan Alquran.

sedangkan manfaat penelitian :

1. Dapat menjadi media belajar mengenal hukum-hukum bacaan Al-quran melalui bahasa alami manusia berupa masukan kalimat berupa teks.

2. Dapat digunakan untuk membantu pembelajaran di sekolah-sekolah Islam, Pondok Pesantren, dan sekolah tinggi atau universitas Islam dalam mempelajari hukum bacaan Alquran dengan melalui NLP.

\section{TINJAUAN PUSTAKA}

Natural Language Processing merupakan salah satu aplikasi Artificial Intelligence (AI) yang dikembangkan agar komputer mengerti dan memahami bahasa alami yang diberikan dan memberi respon hasil pengolahan sesuai yang diinginkan.(Operation, 2010)

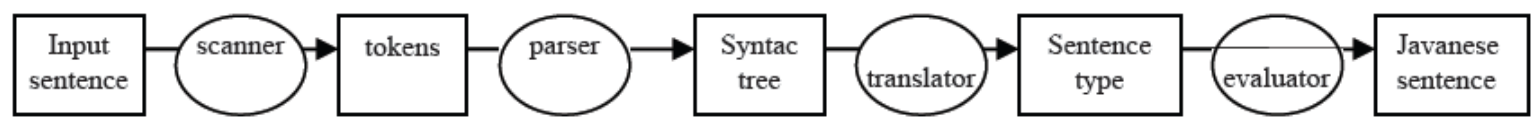

Gambar 1. Komponen NLP untuk translate kalimat Indonesia ke kalimat jepang

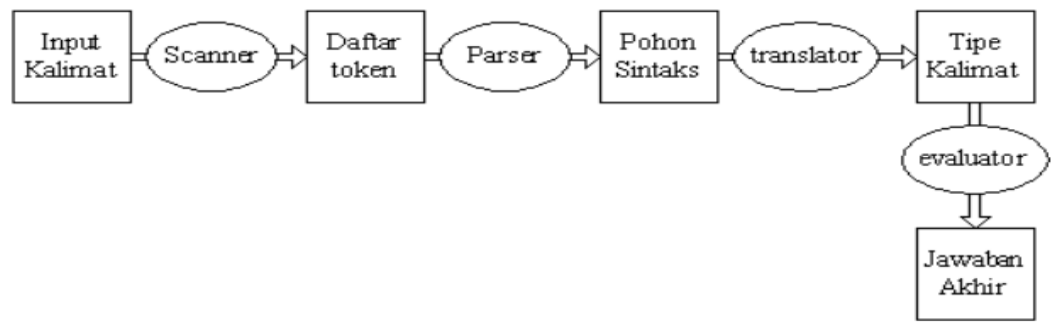

Gambar 2. Komponen pengolah bahasa alami untuk operasi query data 
Dimasukkan akan melewati proses yang dilakukan oleh scanner, parser, translator dan evaluator sebelum mendapatkan jawaban akhir (Operation, 2010).

\section{METODE PENELITIAN}

\section{Metodologi Pengembangan Sistem}

Metodologi rekayasa perangkat lunak yang digunakan model air terjun (waterfall model). Metode ini mempunyai pendekatan sekuensial yang sistematis yang meliput (Silberschatz,K,2005).

1. Rekayasa dan pemodelan sistem

2. Analisis kebutuhan perangkat lunak

3. Perancangan (desain)

4. Penulisan program (coding)

5. Pengujian (testing)

6. Pemeliharaan(maintenance)

\section{HASIL DAN PEMBAHASAN}

Pada awal aturan produksi yang dibuat dengan menentukan "tampilkan" sebagai predikat yang harus ada dan menggunakan bahasa bebas konteks yang terdiri dari aturan surat, ayat, hukum. Data Pertanyaaan yang diinginkan oleh pengguna yaitu santri.

1. Ketikan : tampilkan surat albaqarah ayat 1 hukum idzhar

2. Ketikan : tampilkan surat albaqarah hukum idzhar ayat 2

3. Ketikan : tampilkan surat albaqarah ayat 2

4. Ketikan : tampilkan surat albaqarah

5. Ketikan : tampilkan hukum idzhar surat albaqarah ayat 2

6. Ketikan : tampilkan hukum idhar ayat 2 surat albaqarah

7. Ketikan : tampilkan hukum idhar ayat 3

8. Ketikan : tampilkan hukum idhar

9. Ketikan : tampilkan ayat 2 surat albaqarah hukum ikhfa

10. Ketikan : tampilkan ayat 3 hukum idhar surat albaqarah

11. Ketikan : tampilkan ayat 1 hukum idhar

12. Ketikan : tampilkan ayat 1

Adapun aturan Produksi tersebut :

1. Aturan Produksi Surat

2. Aturan Produksi Ayat

3. Aturan Produksi Hukum

\section{Aturan Produksi Surat}

Surat $\rightarrow$ \{Tampilkan, Tampilkan Surat, Tampilkan Surat Ayat, Tampilkan Surat Hukum, Tampilkan Surat Ayat Hukum, Tampilkan Surat Hukum Ayat\}

Aturan Produksi Surat sebagai berikut:

a. $<$ Tampilkan $><$ surat $>$

$<$ Tampilkan $>::=<$ surat $>$

$<$ surat $>::\{<$ surat $>\}<$ nama surat $>$

$<$ nama surat $>::=$ alfatihah|albaqarah|alimran|annisa

Contoh kalimat:

contoh : Tampilkan Surat alfateha

b. $<$ Tampilkan $><$ Surat $><$ Ayat $>$

$<$ Tampilkan $>::<$ Surat $><$ Ayat $>$

$<$ surat $>::\{<$ surat $>\} \mid<$ Ayat $>$

$<$ surat $>::\{<$ surat $>\}<$ nama surat $>$

$<$ nama surat $>::=$ alfatihah|albaqarah|alimran|annisa

$<$ ayat $>::\{<$ ayat $>\}<$ nomor ayat $>$

$<$ nomor ayat $>::=1|2| 3|4| 5|6| . . \mid 200$

contoh Tampilkan Surat Alfateha Ayat 4

c. $<$ Tampilkan $><$ Surat $><$ Hukum $>$

$<$ Tampilkan $>::<$ Surat $><$ Hukum $>$

$<$ surat $>::\{<$ surat $>\} \mid<$ hukum $>$

$<$ surat $>::\{<$ surat $>\}<$ nama surat $>$

$<$ nama surat $>::=$ alfatihah|albaqarah|alimran|annisa

$<$ Hukum>::\{<hukum>\}<nama hukum bacaan> 
<nama hukum

bacaan>::idhar|qolqolah|iqlab|idhghombigunnah|

idghombilagunnah|ikhfak

contoh Tampilkan Surat Alfateha Hukum Idhar

d. $<$ Tampilkan $><$ Surat $><$ Ayat $><$ Hukum $>$

$<$ Tampilkan $>::<$ Surat $><$ Ayat $><$ Hukum $>$

$<$ surat $>::\{<$ surat $>\} \mid<$ Ayat $>\mid<$ hukum $>$

$<$ surat $>::\{<$ surat $>\}<$ nama surat $>$

$<$ nama surat $>::=$ alfatihah|albaqarah|alimran|annisa

$<$ ayat $>::\{<$ ayat $>\}<$ nomor ayat $>$

$<$ nomor ayat $>::=1|2| 3|4| 5|6| . . \mid 200$

$<$ hukum $>::\{<$ hukum $>\}<$ nama hukum $>$

<nama hukum

bacaan>::idhar|qolqolah|iqlab|idhghombigunnah|

idghombilagunnah|ikhfak

contoh Tampilkan Surat Alfateha Ayat 4 Hukum Idhar

e. $<$ Tampilkan $><$ Surat $><$ Hukum $><$ Ayat $>$

$<$ Tampilkan $>::<$ surat $><$ Hukum $><$ ayat $>$

$<$ surat $>::\{<$ surat $>\} \mid<$ hukum $>\mid<$ ayat $>$

$<$ surat $>::\{<$ surat $>\}<$ nama surat $>$

$<$ nama surat $>::=$ alfatihah|albaqarah|alimran|annisa

$<$ Hukum $>::\{$ hhukum $>\}<$ nama hukum bacaan $>$

$<$ nama hukum bacaan>::idhar|qolqolah|iqlab|idhghombigunnah|

idghombilagunnah|ikhfak

$<$ Ayat $>::\{<$ ayat $>\}<$ nomor ayat $>$

$<$ nomor ayat $>::=1|2| 3|4| 5|6| . . \mid 200$

contoh Tampilkan Surat Alfateha Hukum Idhar Ayat 4

$\mathrm{T} \rightarrow \mathrm{S}|\mathrm{SA}| \mathrm{SH}|\mathrm{SAH}| \mathrm{SHA}$

2. Aturan Produksi Ayat

Ayat $\rightarrow$ \{Tampilkan, Tampilkan Ayat, Tampilkan Ayat Surat, Tampilkan Ayat Hukum, Tampilkan Ayat Surat Hukum, Tampilkan Ayat Hukum Surat\}

Aturan Produksi Ayat sebagai berikut:

\section{a. $<$ Tampilkan $><$ Ayat $>$}

$<$ Tampilkan $>::=<$ Ayat $>$

$<$ Ayat $>: \because\{$ ayat $>\}<$ nomor ayat $>$

$<$ nomor ayat $>::=1|2| 3|4| 5|6| . .200$

Contoh kalimat:

Contoh :Tampilkan Ayat 1

b. $<$ Tampilkan $><$ Ayat $><$ Surat $>$

$<$ Tampilkan $>::<$ Ayat $><$ Surat $>$

$<$ Ayat $>::\{<$ ayat $>\} \mid<$ surat $>$

$<$ Ayat $>::\{<$ ayat $>\}<$ nomor ayat $>$

$<$ nomor ayat $>::=1|2| 3|4| 5|6| . . \mid 200$

$<$ surat $>:$ : $<$ surat $>\}<$ nama surat $>$

$<$ nama surat $>::=$ alfatihah|albaqarah|alimran|annisa

contoh Tampilkan Ayat 4 Surat Alfatehah

c. $<$ Tampilkan $><$ Ayat $><$ Hukum $>$

$<$ Tampilkan $>::<$ Ayat $><$ Hukum $>$

$<$ Ayat $>::\{<$ Ayat $>\} \mid<$ hukum $>$

$<$ Ayat $>::\{<$ ayat $>\}<$ nomor ayat $>$

$<$ nomor ayat $>::=1|2| 3|4| 5|6| . . \mid 200$

$<$ hukum>:: $\{<$ hukum $>\}<$ nama hukum $>$

$<$ nama hukum

bacaan>::idhar|qolqolah|iqlab|idhghombigunnah| idghombilagunnah|ikhfak

contoh Tampilkan Ayat 4 Hukum Idhar

d. $<$ Tampilkan $><$ Ayat $><$ Surat $><$ Hukum $>$

$<$ Tampilkan $>::<$ Ayat $><$ Surat $><$ Hukum $>$

$<$ ayat $>::\{<$ ayat $>\} \mid<$ surat $>\mid<$ hukum $>$

$<$ Ayat $>::\{<$ ayat $>\}<$ nomor ayat $>$

$<$ nomor ayat $>::=1|2| 3|4| 5|6| . . \mid 200$

$<$ surat $>::\{<$ surat $>\}<$ nama surat $>$ 
$<$ nama surat $>:=$ alfatihah|albaqarah|alimran|annisa

$<$ Hukum $>::\{<$ <ukum $>\}<$ nama hukum bacaan $>$

$<$ nama hukum bacaan>::idhar|qolqolah|iqlab|idhghombigunnah| idghombilagunnah|ikhfak

contoh Tampilkan Ayat 4 Surat Alfateha Hukum Idhar

e. $<$ Tampilkan $><$ Ayat $><$ Hukum $><$ Surat $>$

$<$ Tampilkan $>::<$ Ayat $><$ Hukum $><$ Surat $>$

$<$ ayat $::\{<$ ayat $>\} \mid<$ hukum $>\mid<$ surat $>$

$<$ Ayat $>::\{<$ ayat $>\}<$ nomor ayat $>$

$<$ nomor ayat $>::=1|2| 3|4| 5|6| . . \mid 200$

$<$ Hukum $>:$ : $\{<$ hukum $>\}<$ nama hukum bacaan $>$

$<$ nama hukum

bacaan>::idhar|qolqolah|iqlab|idhghombigunnah|

idghombilagunnah|ikhfak

$<$ surat $>::\{<$ surat $>\}<$ nama surat $>$

$<$ nama surat $>:$ :=alfatihah|albaqarah|alimran|annisa

contoh Tampilkan Ayat 4 Hukum Idhar Surat Alfateha

$\mathrm{T} \rightarrow \mathrm{A}|\mathrm{AS}| \mathrm{AH}|\mathrm{ASH}| \mathrm{AHS}$

\section{Aturan Produksi Hukum}

Hukum $\rightarrow$ \{Tampilkan, Tampilkan Hukum, Tampilkan Hukum Surat, Tampilkan Hukum Ayat, Tampilkan Hukum Surat Ayat, Tampilkan Ayat Surat\}

Aturan Produksi Hukum sebagai berikut:

a. $<$ Tampilkan $>$ Hukum

$<$ Tampilkan $>::=<$ Hukum $>$

$<$ Hukum $>::\{<$ hukum $>\}<$ nama hukum bacaan $>$

$<$ nama hukum

bacaan>::idhar|qolqolah|iqlab|idhghombigunnah|

idghombilagunnah|ikhfak

aturan: $\mathrm{T}-->\mathrm{S}|\mathrm{A}| \mathrm{H}$

Contoh kalimat:

contoh : Tampilkan Hukum idhar

b. $<$ Tampilkan $>$ Hukum Surat

$<$ Tampilkan $>::<$ Hukum $><$ Surat $>$

$<$ hukum $>::\{<$ hukum $>\} \mid<$ surat $>$

$<$ hukum $>::\{<$ hukum $>\}<$ nama hukum $>$

<nama hukum

bacaan>::idhar|qolqolah|iqlab|idhghombigunnah|

idghombilagunnah|ikhfak

$<$ surat $>:$ : $\{$ surat $>\}<$ nama surat $>$

$<$ nama surat $>::=$ alfatihah|albaqarah|alimran|annisa

contoh Tampilkan Hukum Idhar Surat Alfateha

c. $<$ Tampilkan $>$ Hukum Ayat

$<$ Tampilkan $>::<$ hukum $><$ Ayat $>$

$<$ hukum $>::\{<$ hukum $>\} \mid<$ surat $>$

$<$ hukum $>::\{<$ hukum $>\}<$ nama hukum $>$

$<$ nama hukum

bacaan>::idhar|qolqolah|iqlab|idhghombigunnah| idghombilagunnah|ikhfak

d. $<$ Tampilkan $>$ Hukum Surat Ayat

$<$ Tampilkan $><$ Hukum $><$ Surat $><$ Ayat $>$

$<$ hukum $>::\{<$ hukum $>\} \mid<$ surat $>\mid<$ ayat $>$

$<$ Hukum $>::\{$ <hukum $>\}<$ nama hukum bacaan $>$

$<$ nama hukum bacaan $>:$ :idhar|qolqolah|iqlab|idhghombigunnah|

idghombilagunnah|ikhfak

e. $<$ Tampilkan $>$ Hukum Ayat Surat

$<$ Tampilkan $><$ Hukum $><$ Ayat $><$ Surat $>$

$<$ hukum $>::\{<$ hukum $>\} \mid<$ ayat $>\mid<$ surat $>$

$<$ Hukum $>::\{<$ hukum $>\}<$ nama hukum bacaan $>$

$<$ nama hukum bacaan>::idhar|qolqolah|iqlab|idhghombigunnah|

idghombilagunnah|ikhfak

$<$ Ayat $: \because\{<$ ayat $>\}<$ nomor ayat $>$

$<$ nomor ayat $>::=1|2| 3|4| 5|6| . .200$

$<$ surat $>::\{<$ surat $>\}<$ nama surat $>$ 
$<$ nama surat $>::=$ alfatihah|albaqarah|alimran|annisa

$<$ surat $>::\{<$ surat $>\}<$ nama surat $>$

$<$ nama surat $>::=$ alfatihah|albaqarah|alimran|annisa

$<$ Ayat $>::\{<$ ayat $>\}<$ nomor ayat $>$

$<$ nomor ayat $>::=1|2| 3|4| 5|6| . . \mid 200$

Tampilkan Hukum Idhar Surat Alfateha Ayat 4

contoh Tampilkan Hukum Idhar Ayat 4 Surat Alfateha

$\mathrm{T} \rightarrow \mathrm{H}|\mathrm{HS}| \mathrm{HA}|\mathrm{HSA}| \mathrm{HAS}$

Pada aturan produksi yang telah ditentukan dilakukan pengecekan dengan scanning yang akan memeriksa input teks dari pengguna.

Pada tahapan proses scanning yang dilakukan adalah

a. Scanning memecah kalimat menjadi kata-kata

Dengan membuat fungsi untuk memecah kalimat denga fungsi ambilperkata

function ambilperkata11(edit1.text,kata,crk);

Contoh : Tampilkan hukum idhar akan memecah kalimat menjadi Field

Tampilkan simpan tabel sumber

Hukum

Idhar

b. Tahapan token yang dilakukan dengan mengenal kata yang ada

Adapun dalam mengenali kata yang ada dengan mengecek beberapa kata diantaranya :

if (DBedit3.text='tampilkan') or (DBedit3.text='surat') or (DBEdit3.text='ayat') or (DBedit3.text='hukum') then

begin

datamodule2.sumber.edit;

hitung_jumlah:=hitung_jumlah+1;

maka akan tampil data sebagai berikut

Field

token

Tampilkan $\quad 1 \quad \rightarrow$ dikenali ditandai 1

Hukum $2 \rightarrow$ dikenali ditandai 2

Idhar

c. Tahapan berikutnya adalah parsing atau melakukan uraiaan terhadap token apakah dalam aturan produksi yang mana dengan sebagai berikut:

Parsing

Field token parsing

Tampilkan $1 \rightarrow$ dikenali $\quad \mathrm{T}->1 \mathrm{~T}$

Hukum $2 \rightarrow$ dikenali $\quad \mathrm{T}->2 \mathrm{~T} \mid \mathrm{H}$

Idhar $\quad \mathrm{T}->2 \mathrm{~T} \mid \mathrm{H}$

Aturan produksi yang ada dilakukan dengan parsing maka sesuai dengan proses query yang ada apakah sesuai dengan permintaan dari user dan dilakukan translator untuk dilakukan proses evaluator sebagai hasil akhir hukum bacaan Alquran sudah cocok atau belum.

Berikut gambar 3. DAD level 0.

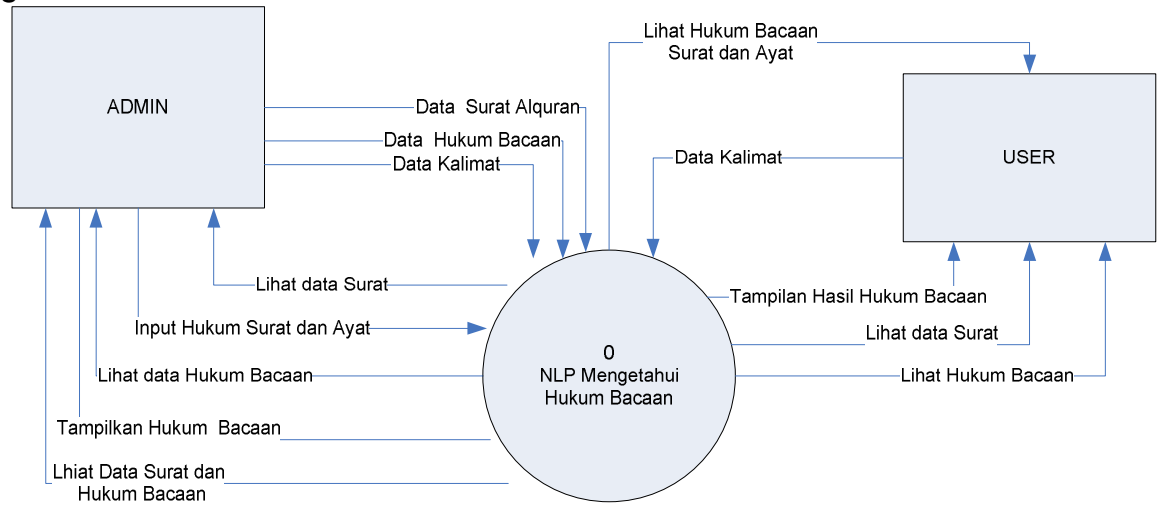

Gambar 3. DAD Level 0

NLP mengetahui hukum bacaan Al-Quran dilakukan oleh seorang admin dan user. Admin 
akan memasukkan data-data yang terkait dengan input data hukum bacaan, input data surat dalam Al-Quran, dan input data kalimat. Seorang user akan memasukkan data kalimat dan terlebih dahulu apakah sesuai dengan sintak dan aturan produksi yang ada pada sistem apabila ada kesalahan akan muncul pesan kesalahan, dan apabila memenuhi aturan produksi akan dilakukan eksekusi tampilan hasilan hukum bacaan Al-Quran yang diinginkan oleh user.

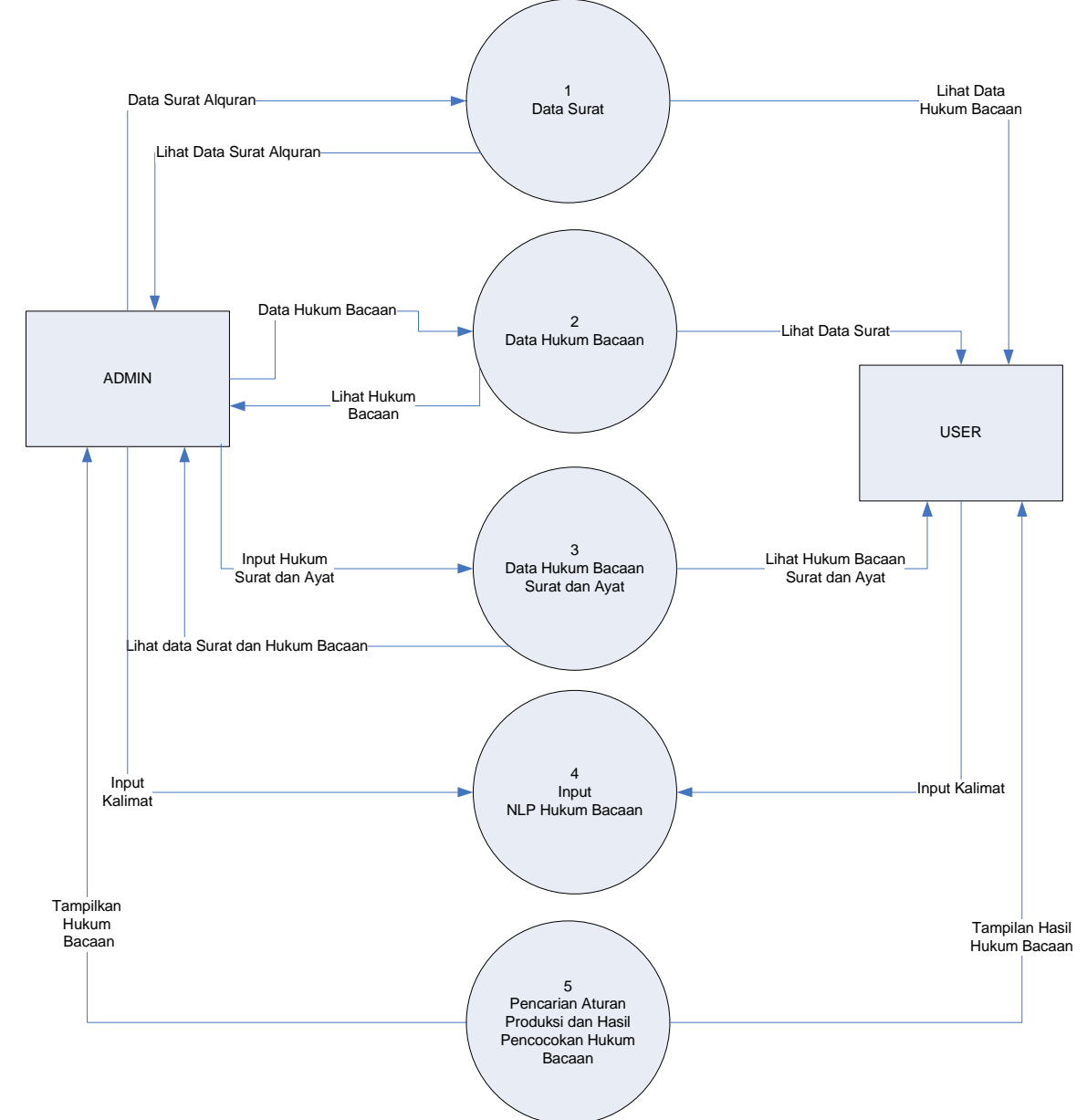

Gambar 4. DAD level 1

Pada Gambar 4. DAD Level 1 proses yang ada terdiri dari admin dan user, admin melakukan proses pengolahan data input data hukum bacaan, data user memasukkan data kalimat untuk dilakukan scanning dan pencocokan apakah sesuai dengan aturan sintak dan apabila sesuai memenuhi sintak yang ada maka tampil hukum bacaan Al-Quran.

Berikut adalah desain tabel yang ada terdiri dari tabel surat Al-quran, tabel hukum bacaan, tabel sumber dan tabel surat ayat dan hukum

Tabel 1. TABEL SURAT ALQURAN

\begin{tabular}{|c|c|c|c|c|}
\hline No & Nama Field & Type & Size & Keterangan \\
\hline 1 & KdSurat & Text & 5 & Kode Surat Alquran \\
\hline 2 & NamaSurat & Text & 25 & Nama Surat Alquran \\
\hline 3 & NomorSurat & Number & 5 & Nomor Surat dalam urutan \\
\hline 4 & JumlahAyat & Number & 5 & $\begin{array}{l}\text { Jumlah Ayat dalam } \\
\text { Alquran }\end{array}$ \\
\hline 5 & Juz & Number & 5 & Juz dalam Alquran \\
\hline 6 & GambarAyat & BLOB & & $\begin{array}{l}\text { Gambar yang ada pada } \\
\text { Ayat }\end{array}$ \\
\hline
\end{tabular}

Data disimpan dalam database dengan tabel Al-Quran berisikan gambar bacaan ayat beserta Kode surat, nama surat, nomor surat, jumlah ayat,dan juz. Setelah data identitas surat Al-Quran tersebut didapat data, maka pengambilan data dari hukum bacaan Al-Quran yang terdiri dari 
hukum bacaan yang ada 5 hukum bacaan yaitu idhar, idghom bigunnah, idghom bilagunnah, ikhfak, iqlab seperti pada tabel 2.

Tabel 2. TABEL HUKUM BACAAN

\begin{tabular}{|l|l|l|l|l|}
\hline No & Nama Field & Type & Size & Keterangan \\
\hline 1 & KdBacaan & Text & 5 & Kode Bacaan Hukum \\
\hline 2 & NamaBacaan & Text & 25 & Nama Hukum Bacaan \\
\hline 3 & GambarBacaan & BLOB & & Gambar Hukum Bacaan \\
\hline
\end{tabular}

Setelah data tersebut direkam dan disimpan dalam tabel hukum bacaan maka dilakukan pengolahan untuk aturan produksi yang ada dalam hitungan dengan tabel sumber seperti pada tabel 3.

Tabel 3. TABEL SUMBER

\begin{tabular}{|l|l|l|l|l|}
\hline No & Nama Field & Type & Size & Keterangan \\
\hline 1 & Nomkata & Text & 5 & Nomor \\
\hline 2 & Kata & Text & 25 & Kata \\
\hline 3 & Letak & Text & 5 & Letak Kata \\
\hline 4 & Aturan & Text & 35 & Aturan Produksi NLP \\
\hline
\end{tabular}

Tabel sumber untuk menyimpan data kata yang kalimat yang dilakukan oleh scanning kata akan dipecah-pecah dan disimpan dalam tabel sumber, lalu setelah disimpan dalam kata-kata yang dipecah dilakukan pengenalan token yang juga disimpan dalam letak kata dan dilakukan parsing dalam mengenali aturan produksi yang ada.

Hasil dari tabel sumber yang sesuai dengan sintak maka kemudian dilakukan translator atau penterjemahan untuk melakukan query dengan membuka tabel surat ayat dan hukum seperti pada tabel 4.

Tabel 4. TABEL SURAT AYAT DAN HUKUM

\begin{tabular}{|l|l|l|l|l|}
\hline No & Nama Field & Type & Size & Keterangan \\
\hline 1 & KdSurat & Text & 5 & Kode Surat Alquran \\
\hline 2 & KdBacaan & Text & 25 & Kode Hukum Bacaan \\
\hline 3 & Ayatke & Text & 5 & Ayat ke \\
\hline 4 & Juzke & Text & 35 & Juz ke \\
\hline 5 & Urut_letak & Text & 3 & Urut Letak \\
\hline 6 & GambarAyat & BLOB & & Gambar Ayat \\
\hline 7 & Tandaditemukansurat & Text & 2 & $\begin{array}{l}\text { Tanda } \\
\text { ditemukan }\end{array}$ \\
\hline 8 & Tandaditemukanayat & Text & 2 & Tanda ayat ditemukan \\
\hline 9 & Tandaditemukanhukumbacaan & Text & 2 & $\begin{array}{l}\text { Tanda } \\
\text { ditemiukan }\end{array}$ \\
\hline
\end{tabular}

Tampilkan data input hukum bacaan sebagai berikut:

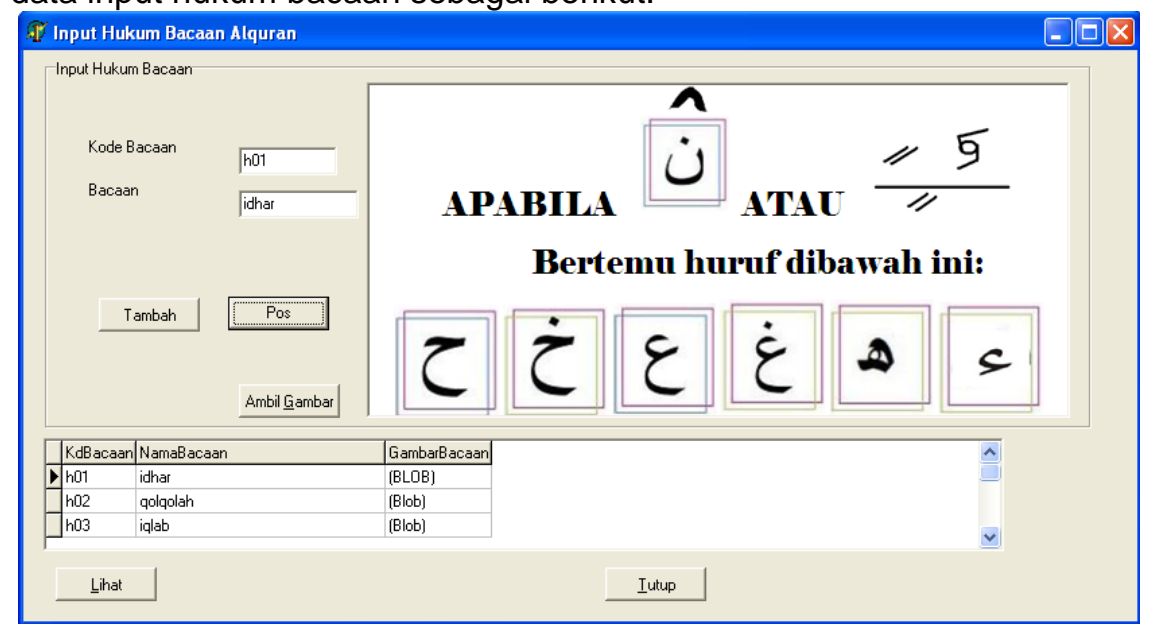

Gambar 5. Input Hukum Bacaan

Gambar 5 merupakan gambar memasukkan data oleh admin untuk hukum bacaan Al-Quran dan memasukkan gambar yang sesuai dengan hukum bacaan Al-Quran yang terdiri dari 5 hukum bacaan yaitu idhar, idghom bigunnah, idghom bilagunnah, ikhfak, iqlab.

Seorang admin juga melakukan input data surat yang ada di Al-Quran sebagai berikut seperti gambar 6 . 


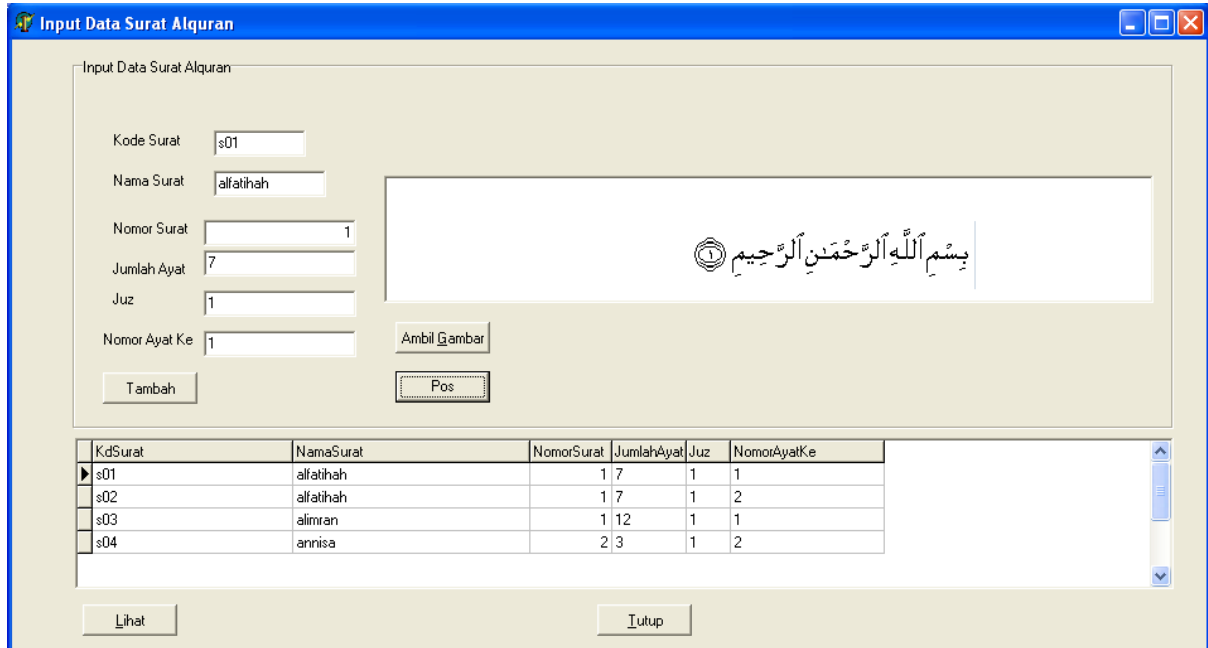

Gambar 6. Input Program Data Surat Al-Quran

Pada user melakukan input data kalimat sebagai berikut : contoh memasukkan kalimat "tampilkan ayat" maka akan ada pesan kesalahan karena ayat harus ada nomor ayat sehingga muncul pesan kesalahan seperti pada gambar.

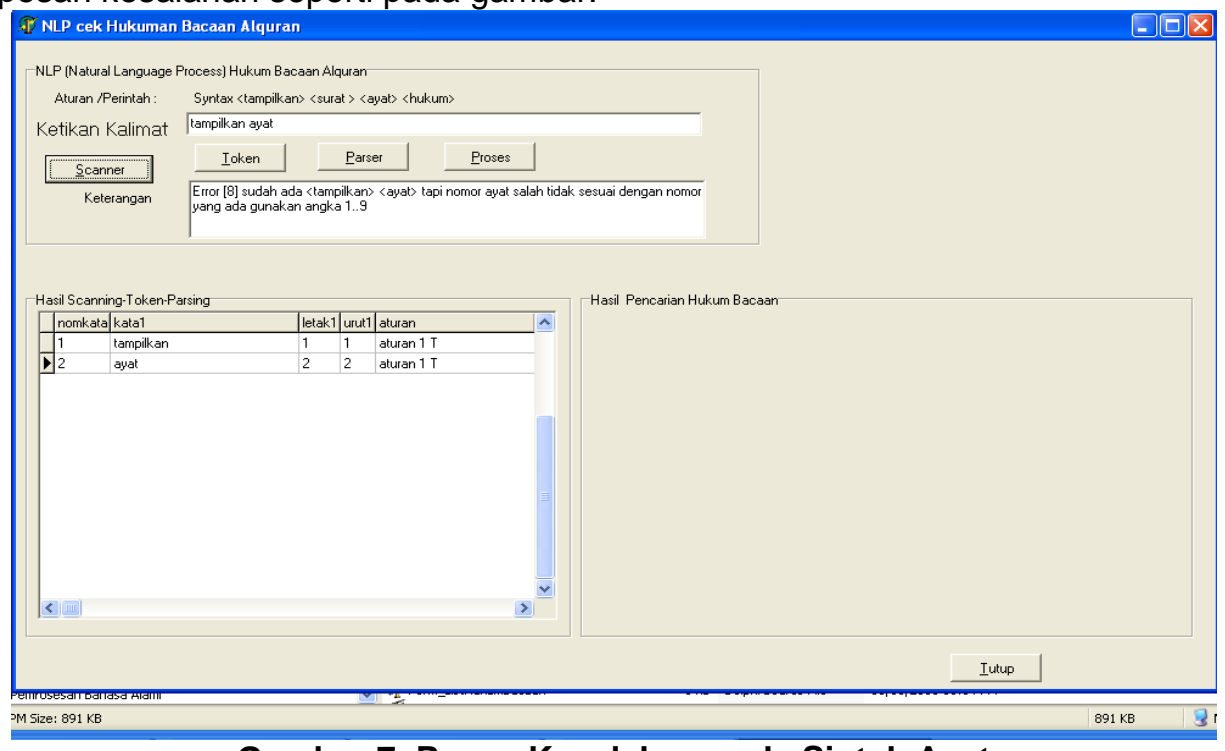

Gambar 7. Pesan Kesalahan pada Sintak Ayat

Berikut contoh untuk "tampilkan ayat 1 surat" sudah benar tetapi sintak surat tidak diisi dengan nama surat maka akan muncul pesan kesalahan sebagai berikut pada gambar 8 .

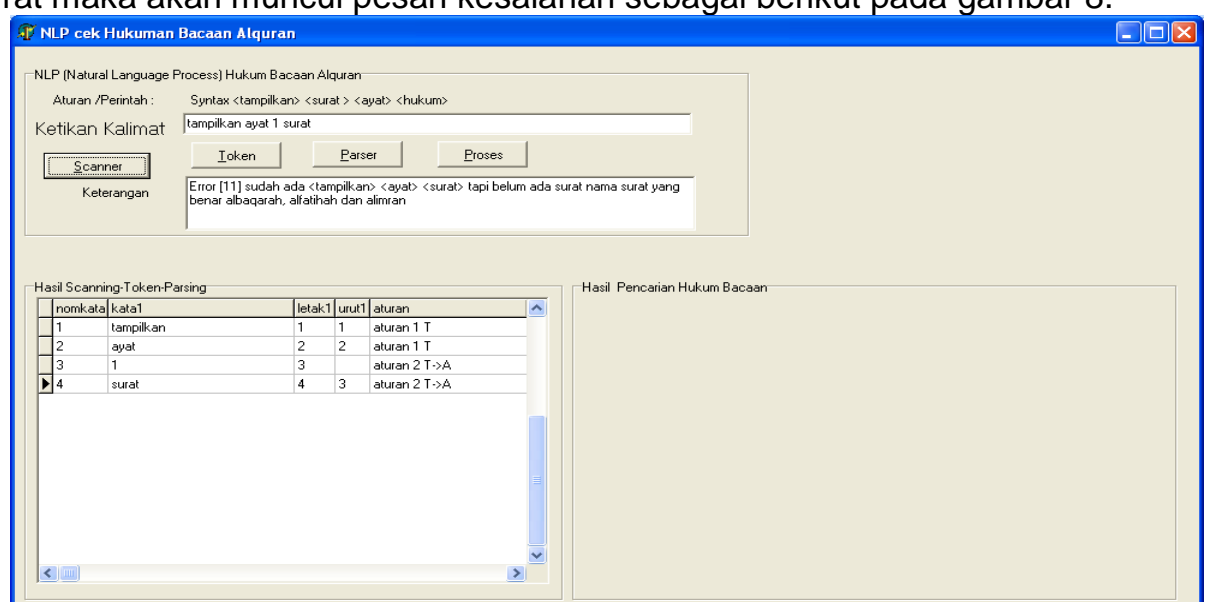

Gambar 8. Pesan kesalahan untuk syntak ayat dan surat 
Pada proses scanning, token dan parsing akan dilakukan pengecekan apabila tidak terdapat pesan kesalahan dan sesuai dengan aturan produksi yang ada dan sintaknya, maka akan dilakukan proses translator untuk mencari query yang ada pada databases berdasarkan input kalimat oleh user seperti pada gambar 9.

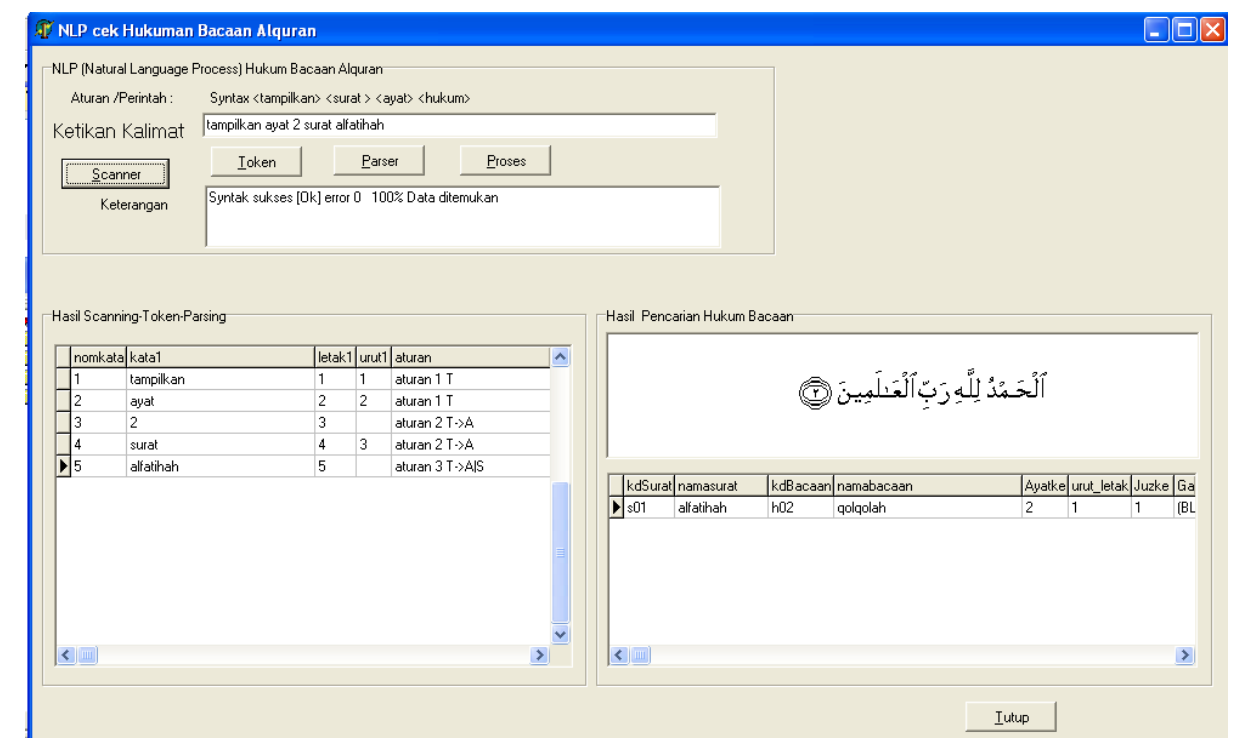

Gambar 9. Hasil tampilan tanpa kesalahan

Data input kalimat yang dilakukan oleh user dilakukan scanning untuk memecah kalimat menjadi kata-kata lalu dilakukan proses token sebagai pengenal kata tersebut apakah dikenal oleh sistem atau tidak dikenali, maka dilakukan proses parsing yang akan menterjemahkan menjadi query yang diinginkan dan dilakukan sehingga akan dieksekusi berupa tampilkan dilayar sesuai dengan yang diinginkan query oleh user. Pada proses tranlator maka selanjutkan akan dilakuakn evaluator apakah sesuai dengan query yang ada sehingga dapat tampil dilayar hasil dari input kalimat berupa tampilan hukum bacaan yang diinginkan oleh user.

\section{KESIMPULAN}

Natural Language Processing (NLP) untuk mengetahui hukum bacaan Al-Quran dapat menganalisis masukan data teks berupa kalimat dengan bahasa manusia sehari-hari proses awal dengan mengenali aturan sintak dan aturan produksi yang ada dengan melalui scanning, mengidentifikasi token, hasil dari token akan dilakukan parsing dan diproses kemudian untuk dilakukan pencocokan dengan aturan produksi yang ada. Hasil input kalimat tersebut dilakuan pengecekan apakah sesuai atau tidak jika tidak sesuai, maka akan muncul pesan kesalahan. Apabila sebaiknya jika tidak ada kesalahan maka proses selanjutnya dari parsing yang diteruskan dengan translator untuk menterjemahkan query yang diinginkan oleh user. Pada proses tranlator maka selanjutkan akan dilakukan evaluator apakah sesuai dengan query yang ada sehingga dapat tampil dilayar hasil dari input kalimat berupa tampilan hukum bacaan yang diinginkan oleh user.

\section{DAFTAR PUSTAKA}

Fakhrudin, Arif, S.Ag, Siti Irhamah, Lc,2010, Al-Qur'an Tafsir Perkata Tajwid Kode Angka, Alhidayah, Kalim

Hartati, S. (2006), Natural Language Processing For Studying Javanese Language Based On Fuzzy Logic and Computational. Operation, S. (2010). Aplikasi Pengolahan bahasa Alami untuk 5 (1), 1-5

Silberschatz, K, (2005), Database Sustems Concept, $5^{\text {th }}$ edt, McGrawHill

Zarkasyi, Imam, KH, 1995, Pelajaran Tajwid, Trimurti Press, Gontor Ponorogo 